\title{
Production of lipase from Micrococcus flavus and influence of bioparameters
}

\author{
Nisha.P ${ }^{1^{*}}$, Nayana.M ${ }^{1}$, Ardra Asokan ${ }^{2}$. \\ $I^{*}, 1$ P.G.Department of Biochemistry and Biotechnology,S.S.V.College, Valayanchirangara,Ernakulam \\ KERALA-683556, \\ 2 Dept of Microbiology,SreeNarayana Guru College, K.G.Chavady.P/O,Coimbatore.
}

\begin{abstract}
Lipase enzymes from microbial sources are currently enormous attention by potential industrial uses. The aim of the study is to investigate some bioparameters affecting lipase production by spectrophotometric method. Extracellular lipase producing organisms isolated from different places of 'ERNAKULAM DIST'(KERALA) and identified as Micrococcus flavus (NYT) by morphological and biochemical characters and 16 rRNA sequencing .Optimization of lipase production and enzyme activity was measured with varying $p H(4-9)$, incubation temperature $\left(27^{\circ} \mathrm{C} \& 37^{\circ} \mathrm{C}\right)$, growth media incubation time $(24 \mathrm{hr}, 48 \mathrm{hr}, 72 \mathrm{hr})$, reaction mixture time intervals $(10,20$ and $30 \mathrm{~min})$ and substrates as sunflower oil and palm oil. The maximum lipase production by using sunflower oil as substrate was recorded at $\mathrm{pH} 8,27^{\circ} \mathrm{C}$ during $48 \mathrm{~h}$ of culture period and 10 min incubation time and in palm oil higher production was at $\mathrm{pH} 7,27^{\circ} \mathrm{C}$ during $48 \mathrm{~h}$ of culture period and 10 min incubation time.
\end{abstract}

Keywords: Enzyme activity,Lipase , ,Micrococcus, Tributryn ,Optimization.

\section{Introduction}

Lipases extensively present in nature, catalyze the hydrolysis and the synthesis of ester formed from glycerol and long chain fatty acids [1]. Plants, animals and microorganisms are capable to producelipase enzymes [2 - 4]. Lipases havingadvantageous properties related to their stability as organic solvent-tolerant [5] and thermo stable enzymes [6].

Microbial lipases are more considerable and greatly demanded sources due to several industrial potentials [7]. Lipases are usually used in large number of fields such as food, dairy, textile, detergent, pharmaceutical and cosmetic industries. These enzymes are also used in the processing of fats and oils, detergents and decreasing formulation, food processing, the synthesis of fine chemicals, pharmaceuticals, $[8,9]$ and paper manufacture, .

Aim of this work is to isolate and characterize the lipolytic bacteria from polluted water from different places of ERNAKULAM DIST(KERALA), optimize the growth parameters for higher lipase production.Organism used for this research work wasMicrococcus flavus(NYT), is foundin everywhere water, dust, air and soil, and as a part of the normal flora of mammalian skin. It is agram positive, yellow pigmented cocci,obligate aerobeand arranged in tetrads. Commercially easily available sunflower oil and palm oil were used as the substrate for the determination of the lipase activity of M. flavus.

\subsection{SAMPLE COLLECTION}

\section{Metrials And Methods}

In this study, water samples were collected from different places of ERNAKULAM DIST and aseptically transfer to the laboratory immediately. The isolation of organisms was done by using serial dilution method.

\section{2 .ISOLATION OF LIPOLYTIC BACTERIA}

Lipase producing organisms were screened by qualitative plate assay. 9 Isolates were separately inoculated on tributyrin agar base plates [containing $0.5 \%(\mathrm{w} / \mathrm{v})$ peptone, $0.3 \%(\mathrm{w} / \mathrm{v})$ yeast, $1 \%(\mathrm{v} / \mathrm{v})$ tributyrin and $2 \%$ agar, $\mathrm{pH} 7.0$ ] and incubated at $30^{\circ} \mathrm{C}$ for 2 days. Zone of clearance due to the hydrolysis of tributyrin was observed. Colony showing clear zone around was taken for the further studies.

\subsection{IDENTIFICATION}

The more potent lipase producer, was identified based on morphological, biochemical and physiological characters and 16SrRNA sequencing. 


\subsection{OPTIMIZATION OF PARAMETERS}

Varying the following parameters one at a time with fermentation media were checked. The parameters were i. incubation period, ii. incubation temperature iii. $\mathrm{pH}$ and iv. lipid substrate. The influence of incubation period and incubation temperature were assessed by culturing NYT in tributryn broth at different time duration $\left(24,48,72\right.$ hours) andwith temperatures of $27^{\circ} \mathrm{C} \&$ $37^{\circ}$ Crespectively . Growth media was adjusted to $\mathrm{pH}$ ranged from 4 to 9 before the inoculation of NYT, to determine the effect of $\mathrm{pH}$ on lipase production.Enzyme activity of all parameters were assessed with sunflower oil as a substrate and varying incubation time such as 10, 20 and 30mins.

\subsection{ENZYME PRODUCTION}

Composition of productionmedium used (tributryin broth) in this work was: peptone $(5 \mathrm{~g})$; yeast $(3 \mathrm{~g})$; tributryin $(10 \mathrm{ml})$; distilled water $(1000 \mathrm{ml})$. NYT was inoculated in to the production media. After the incubation time, culture broth was centrifuge at $4^{0} \mathrm{C}, 4000 \mathrm{rpm}$ for 15 minutes, for the separation of an enzyme and the supernatant was used as an enzyme source for further studies. Determination of lipase activity of an organism is done by colorimetric assay of lipase activity using copper soap method [10].

\subsection{LIPASE ACTIVITY ASSAY}

$0.3 \mathrm{ml}$ of substrate taken as reagent blank, vortex and centrifuge 5 minutes at $1000 \mathrm{x} \mathrm{g}$, room temperature. $0.5 \mathrm{ml}$ of enzyme added with $25 \mathrm{ml}$ of substrate to initiate lipolysis on the emulsion substrate, start timer, and continue stirring. Remove duplicate $0.3 \mathrm{ml}$ subsample of the reaction mixture at pre determined time intervals (e.g.: 10, 20, 30 minutes) and place $5 \mathrm{ml}$ of benzene and $1 \mathrm{ml}$ of cupric acetate/pyridine reagent. Immediately vortex to stop the reaction and form colored fatty acid cupric soaps. Centrifuge 5 minutes at $1000 \mathrm{x}$ $\mathrm{g}$, room temperature, to obtain the clear benzene upper phase. Measure at the A715 nm for the benzene layer of each sample using glass cuvettes.

\section{Results And Discussion}

In this study, the lipase producing bacterial strain was isolated from ERNAKULAM DIST and identified as Micrococcus flavus(Table-1). Optimization of an enzyme production and yields were assessed at different incubation period $(24 \mathrm{hr}, 48 \mathrm{hr}, 72 \mathrm{hr})$, temperature $\left(27^{\circ} \mathrm{C} \& 37^{\circ} \mathrm{C}\right)$ and at $\mathrm{pH}(4-9)$ by using substrate as sunflower oil (Fig - 1) and palm oil (Fig - 2). The higher production of lipase enzyme was $18.4935 \mathrm{IU} / \mathrm{L}$ in sunflower oil and $12.1832 \mathrm{IU} / \mathrm{L}$ was in palm oil as substrate.

From the values of lipase assay, the maximum lipase production recorded at $\mathrm{pH} 8$ when sunflower oil used as substrate and in palm oil the higher production at $\mathrm{pH}$ 7. Related work on Bacillus mycoides[11], has the maximum lipase activity on $\mathrm{pH} 7$ the lipase activity was less in low and high medium $\mathrm{pH}$ tested, In both substrates, NYT has an optimum incubation temperature at $27^{\circ} \mathrm{C}$ while comparatively less activity was obtained at $37^{\circ} \mathrm{C}$. Similar study was reported [12] isolated 5 Bacillus strain from oil mill waste and analyze their lipase activity and optimization ,the maximum lipase production was at $\mathrm{pH}-7$, substrate concentration (coconut oil) at $0.5 \%$ and at $24 \mathrm{hr}$. NYT shows higher lipase activity during $48 \mathrm{hr}$ of culture period and at incubation time 10 mins than other two incubation times in sunflower oil and also in palm oil. Streptomyces griseushas achievedthe maximum activity at $24 \& 48 \mathrm{~h}$ of incubation period using sunflower oil and palm oil as a substrate [13].

\section{Figures And Tables}

TABLE 1- CHARACTERS OF NYT

\begin{tabular}{|l|l|l|}
\hline S1 No & $\begin{array}{l}\text { Biochemical } \\
\text { test }\end{array}$ & Result \\
\hline 1 & Grams reaction & + \\
\hline 2 & Shape & Cocci,Tetrads. \\
\hline 3. & $\begin{array}{l}\text { Aerobic } \\
\text { growth }\end{array}$ & + \\
\hline 4. & $\begin{array}{l}\text { Growth above } \\
40^{0} \mathrm{C}\end{array}$ & - \\
\hline 5. & $\begin{array}{l}\text { Mac conkey } \\
\text { growth }\end{array}$ & NLF colonies. \\
\hline 6. & Motility & - \\
\hline 7. & Endospore & - \\
\hline 8. & Capsule & + \\
\hline 9. & $\begin{array}{l}\text { Starch } \\
\text { hydrolysis }\end{array}$ & + \\
\hline
\end{tabular}




\begin{tabular}{|l|l|l|}
\hline 10. & $\begin{array}{l}\text { Gelatin } \\
\text { hydrolysis }\end{array}$ & - \\
\hline 11. & $\begin{array}{l}\text { Glucose } \\
\text { fermentation }\end{array}$ & - \\
\hline 12. & $\begin{array}{l}\text { Lactose } \\
\text { fermentation }\end{array}$ & - \\
\hline 13. & $\begin{array}{l}\text { Sucrose } \\
\text { fermentation }\end{array}$ & - \\
\hline 14. & $\begin{array}{l}\text { Manitol } \\
\text { fermentation }\end{array}$ & - \\
\hline 15. & $\begin{array}{l}\mathrm{H}_{2} \text { S } \\
\text { production }\end{array}$ & + \\
\hline 16. & Indole test & - \\
\hline 17. & Methyl red & - \\
\hline 18. & VP & + \\
\hline 19. & Citrate & + \\
\hline 20. & Catalase & + \\
\hline 21 & Oxidase & + \\
\hline 22. & Urease & + \\
\hline 23. & 6.5\% NaCl & + \\
\hline & Pigmentation & Yellow \\
\hline & Identify(genus) & Micrococcus $s p$ \\
\hline & & \\
\hline
\end{tabular}

FIGURE- 1- LIPASE ACTIVITY (IU/L) ON SUNFLOWER OIL
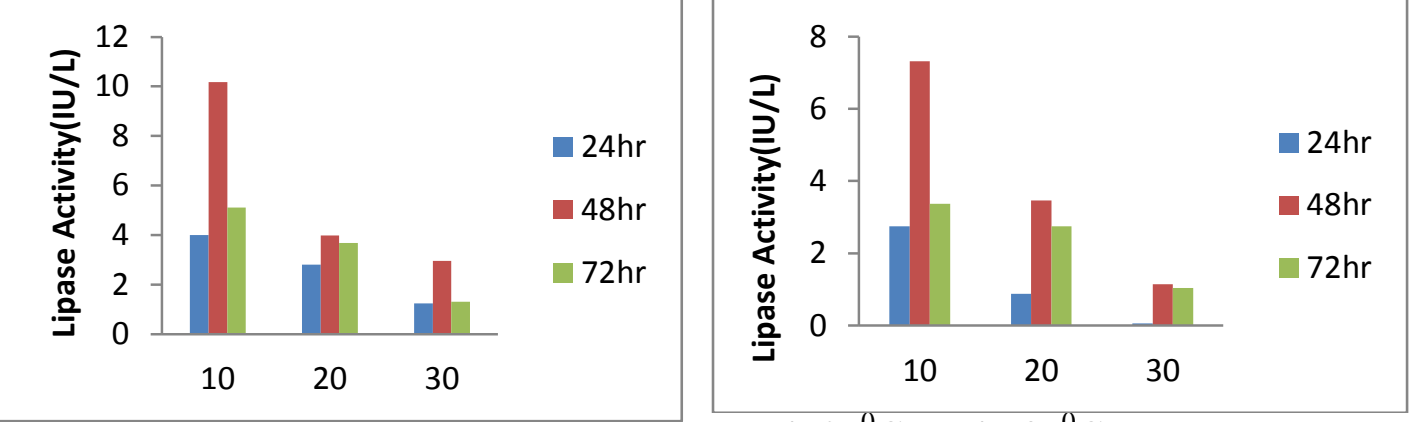

$\mathrm{pH}-4,27^{\circ} \mathrm{CpH}-4,37^{\circ} \mathrm{C}$

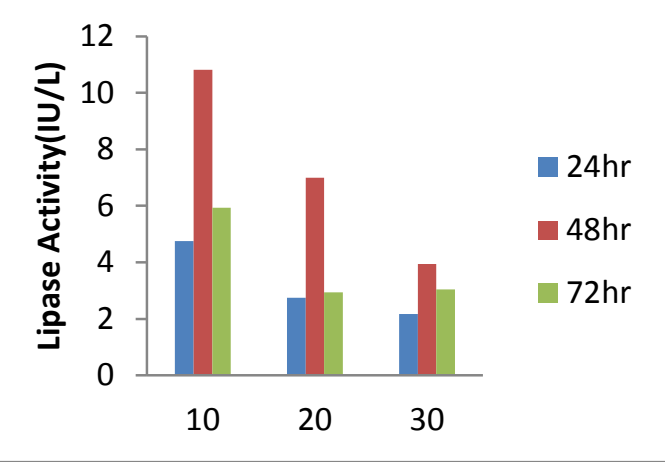

$\mathrm{pH}-5,27^{0} \mathrm{C}$

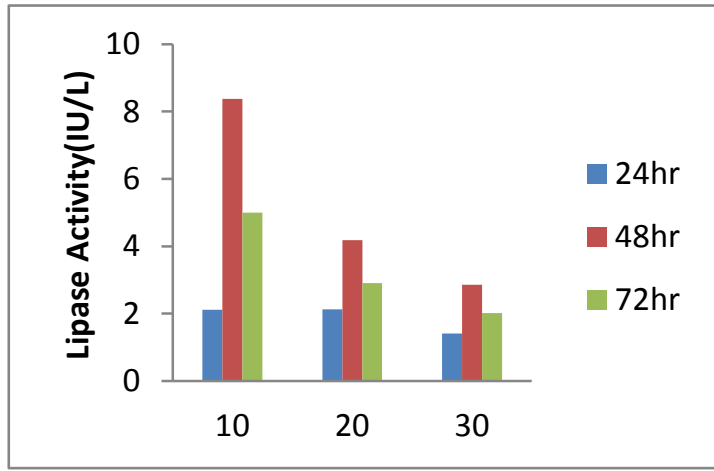

$\mathrm{pH}-5,37^{0} \mathrm{C}$
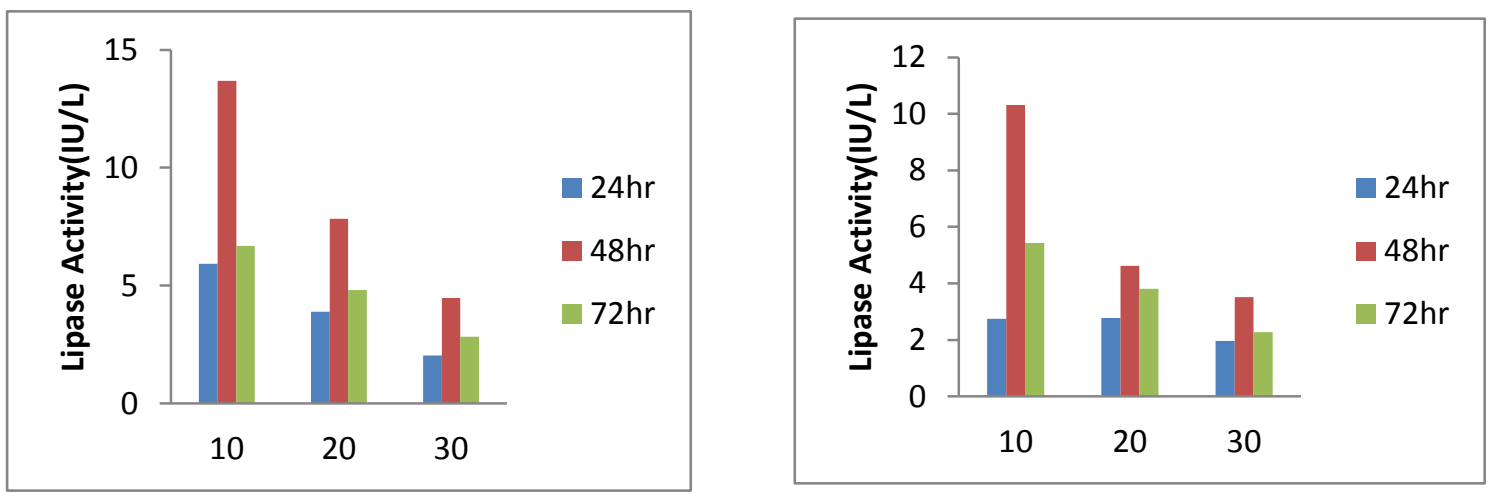
pH-6, $27^{0} \mathrm{C}$

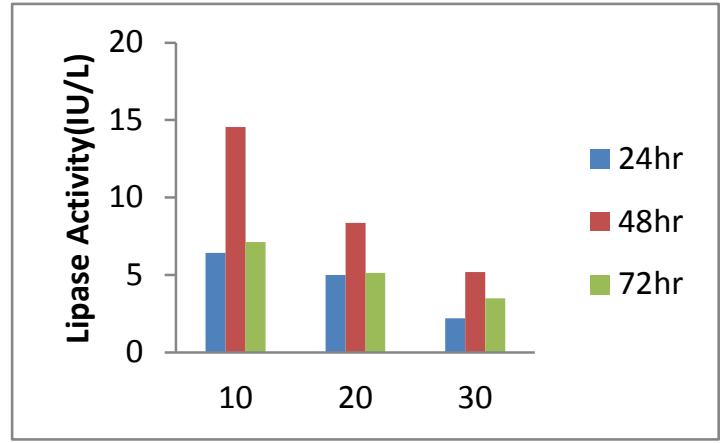

$\mathrm{pH}-7,27^{0} \mathrm{C}$

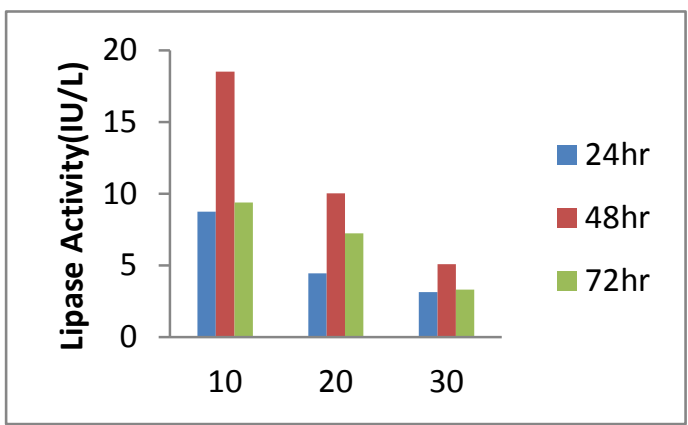

PH- $8,27^{0} \mathrm{C}$

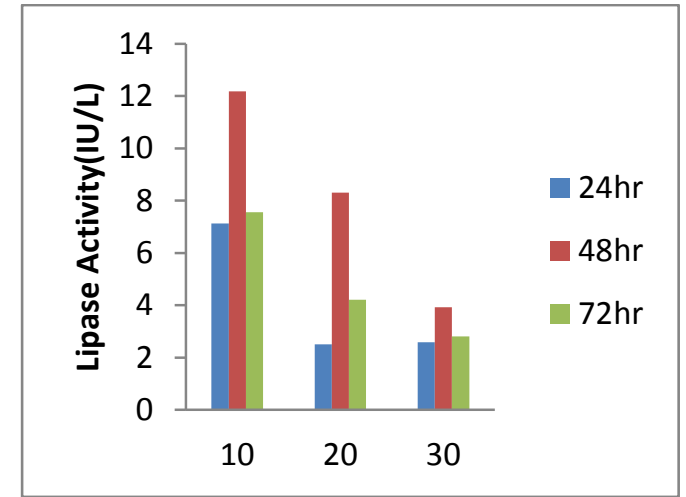

pH-9, $27^{0} \mathrm{C}$

FIGURE- 1- LIPASE ACTIVITY(IU/L) ON PALM OIL

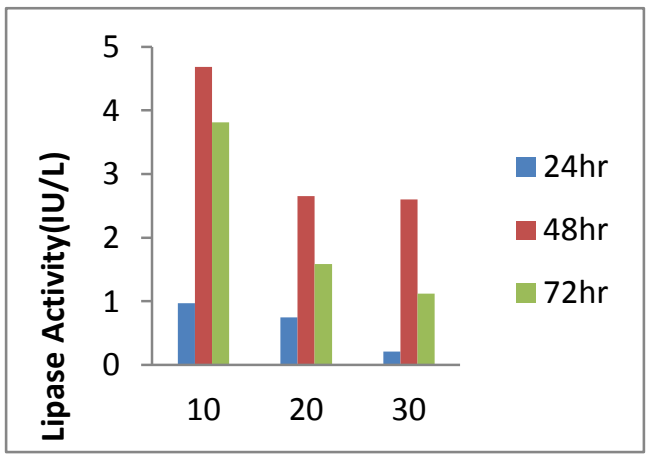

$\mathrm{pH}-4,27^{0} \mathrm{C}$
$\mathrm{pH}-6,37^{\circ} \mathrm{C}$

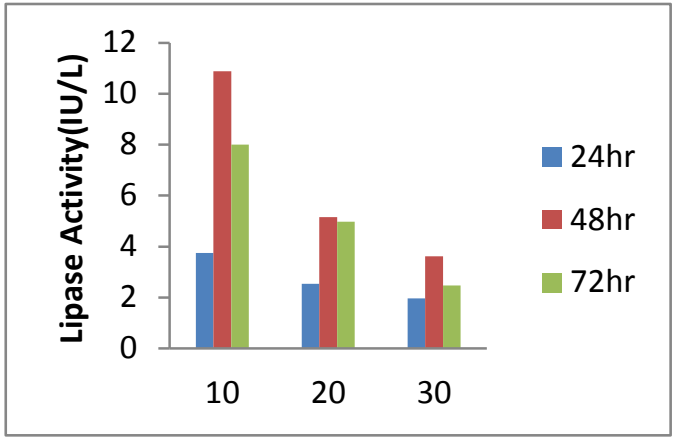

$\mathrm{pH}-7,37^{0} \mathrm{C}$

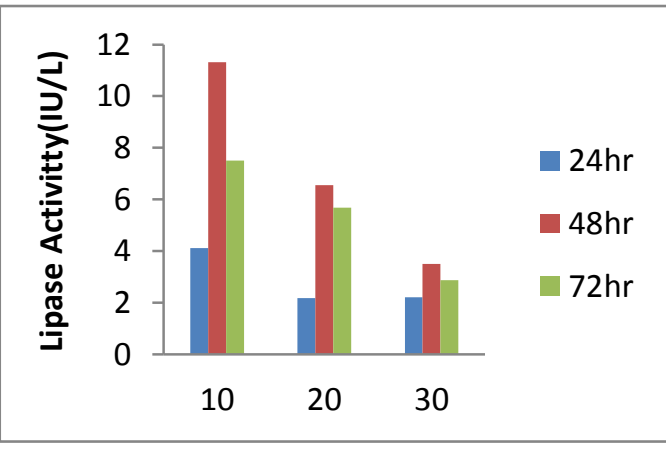

$\mathrm{PH}-8,37^{0} \mathrm{C}$

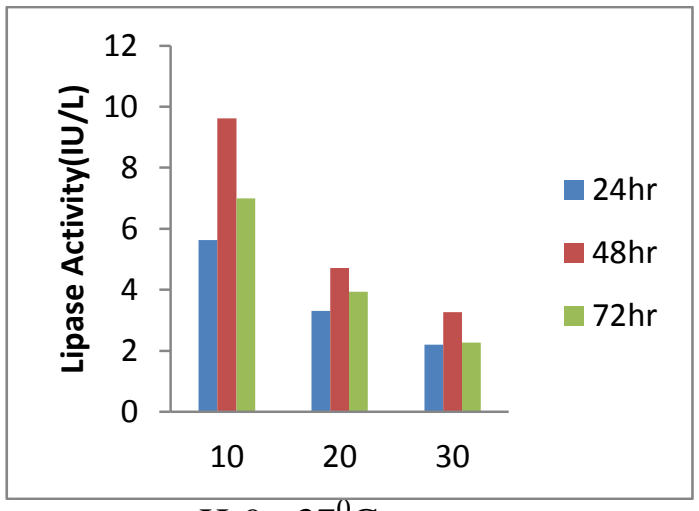

$\mathrm{pH}-9,37^{0} \mathrm{C}$

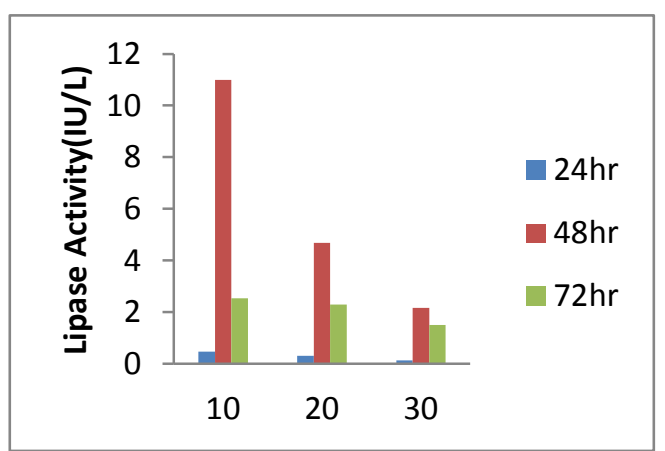

$37^{0} \mathrm{C}$ 


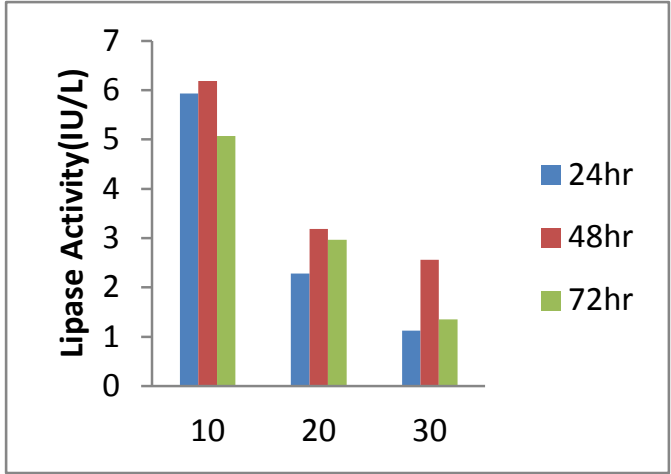

PH-5, $27^{0} \mathrm{C}$

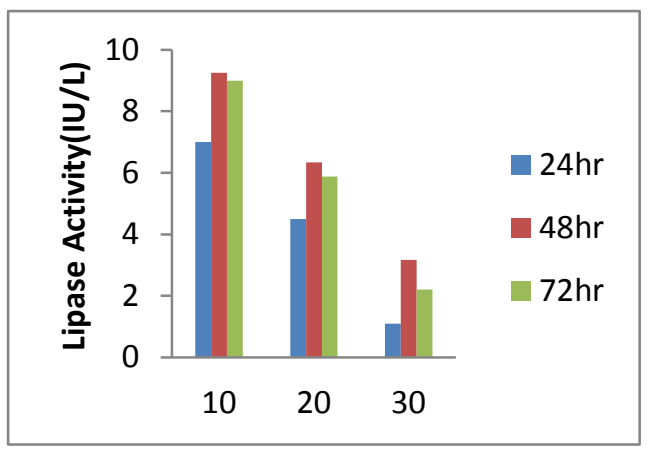

pH-6, $27^{0} \mathrm{C}$

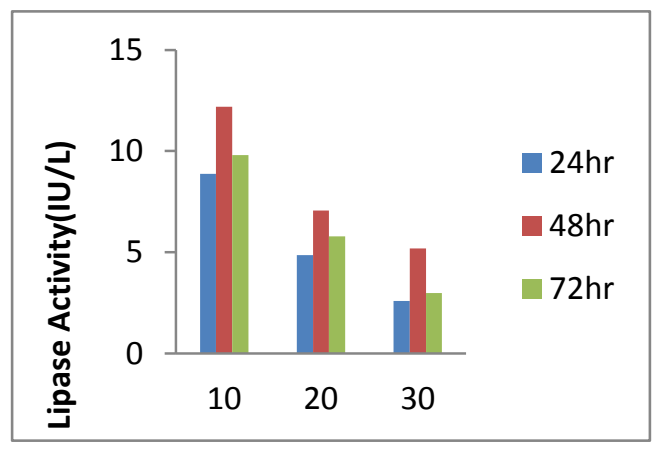

$\mathrm{pH}-7,27^{0} \mathrm{C}$

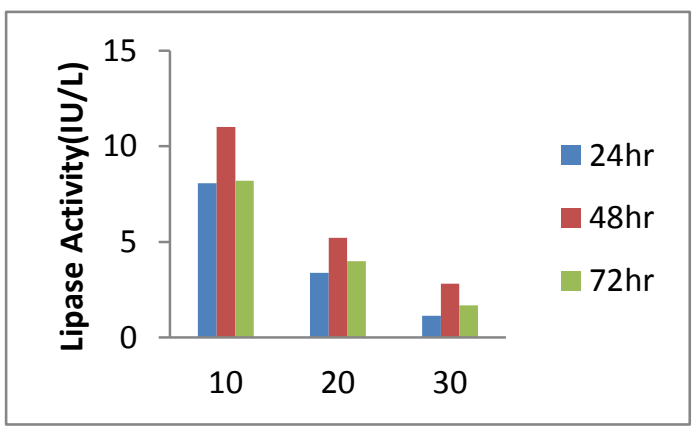

$\mathrm{pH}-8,27^{0} \mathrm{C}$

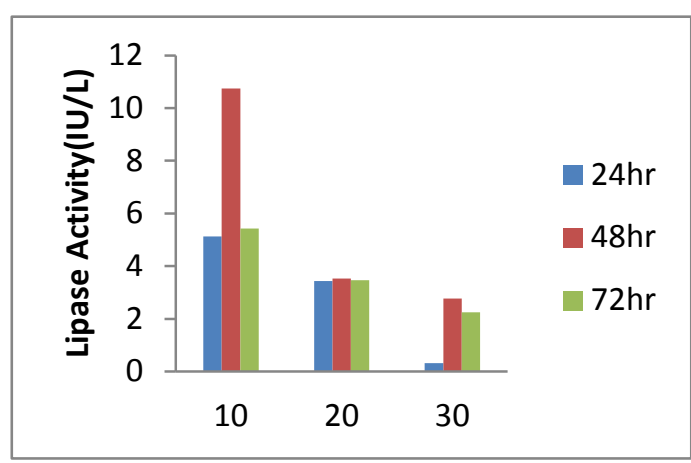

$37^{0} \mathrm{C}$

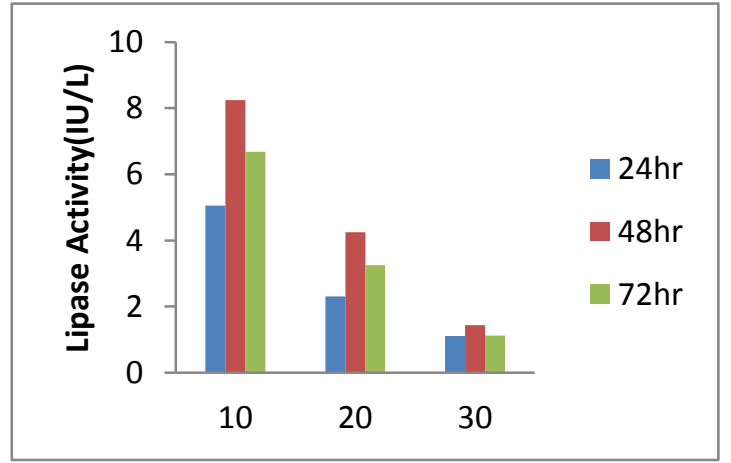

$37^{0} \mathrm{C}$

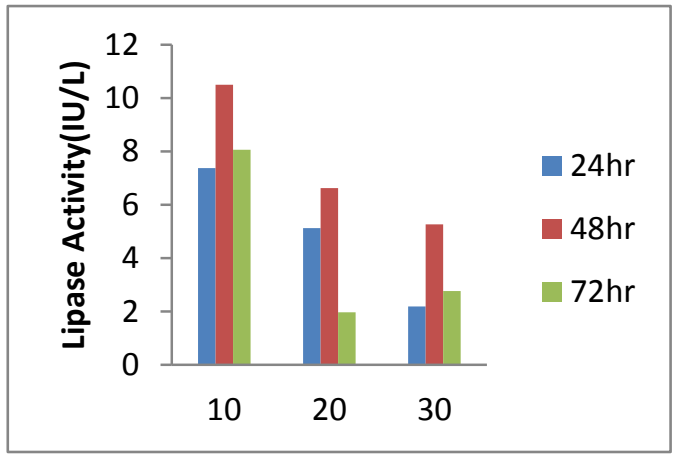

$37^{0} \mathrm{C}$

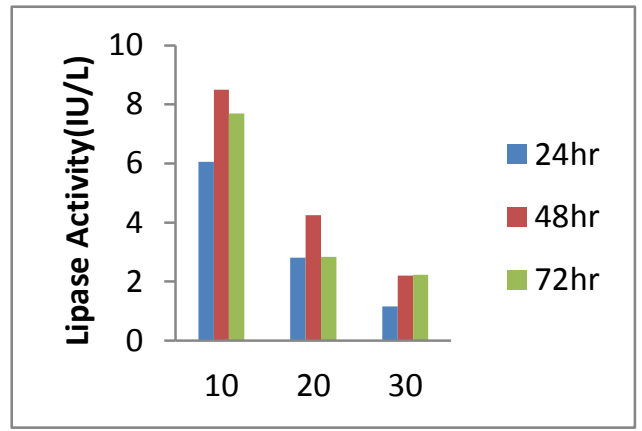

$\mathrm{pH}-8,27^{0} \mathrm{C}$ 


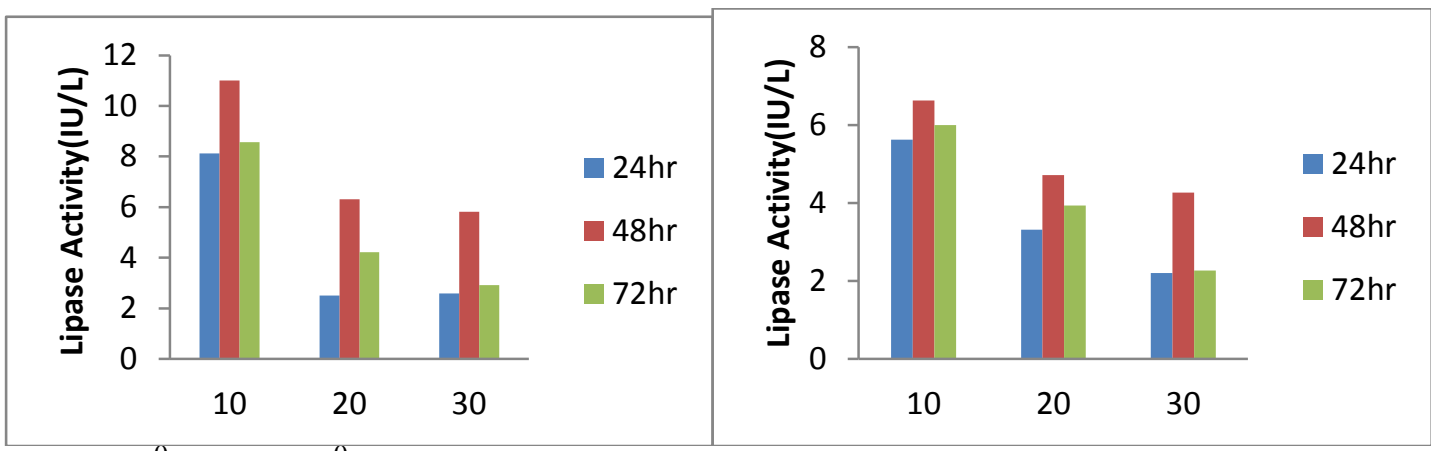

$\mathrm{pH}-9,27^{0} \mathrm{CpH}-937^{0} \mathrm{C}$

\section{Conclusion}

The bacteria isolated from different places of ERNAKULAM DIST was screened extracellular lipase production by qualitative plate assay (tributyrin agar base plate method) and identified as Micrococcus flavus by morphological and biochemical characters and also by sequencing. . Lipase activity(colorimetric assay by copper soap method) was measured with varying $\mathrm{pH}(4-9)$,incubation temperature $\left(27^{0} \mathrm{C} \& 37^{\circ} \mathrm{C}\right.$,) varying incubation time such $24 \mathrm{hr}, 48 \mathrm{hr}$ and $72 \mathrm{hr}$ with sunflower oil and palm oil as substrates.

The optimal growth conditions for the maximum lipase production by Micrococcus flavuswas recorded at $\mathrm{pH}$ $8,27^{\circ} \mathrm{Cof}$ incubation temperature, during $48 \mathrm{hr}$ of culture period and reaction mixture incubation time $10 \mathrm{mins}$ in both substrates, comparatively higher lipase production was in sunflower oil as a substrate.

\section{References}

[1] . Karl-Erich Jaeger ND Manifred T. Reetz.Microbial lipases from versatile tools for biotechnology.TIBTECH 1998;396-403:16.

[2]. Carriere F, Thirstrup K, Hjorth S. Cloning of the classical guinea pig pancreatic lipase and comparison with the lipase related protein 2. FEBS Lett. 1994;388-63:8

[3]. Bhardwaj K, Raju A, Rajasekharan R. Identification, purification and characterization of a thermally stable lipase from rice bran. A new member of the (phospho) lipase family. Plant Physiol. 2001;127-1728:38.

[4] . Olempska-Beer ZS, Merker RI, Ditto MD.Food processing enzymes from recombinant microorganisms- $A$ review.RegToxicolPharmacol. 2006;45-144:58.

[5] . Rahman RNZRA, Baharum SN, Basri M, et al. High-yield purification of an organic solvent-tolerant lipase from Pseudomonas sp strain S5 Anal Biochem. 2005;341-267:74.

[6] . Li H, Zhang X. Characterization of thermostable lipase from thermophilicGeobacillussp TW1.Protein ExprPurif.2005; 42-153:9.

[7] . Hasan .F and A.Hameed.,Optimization of lipase production from Bacillus sp. Pak.J.Bot(Special Issue)2006.

[8]. Rubin B, Dennis EA, editors. Lipases: Part A. Biotechnological methods in enzymology .vol 284. New York. Academic press, 1997a pp.1-408

[9] . Kazlauskas RJ, Bornsescheuer UT, Bio transformations with lipases.In:Rehm HJ, Pihler G, Stadler A, Kelly PJW, editors. Bio technology.Vol 8. New York:VCH,1998,pp.37-192.

[10] . PraphanPinsirodom and Krik L. Parkin,Current protocols in food analytical chemistry 2001;C3.1.1:C31.13.

[11] . Achamma, T., Manoj, M. K., Valsa, A., Mohan, S. and Manjula, R. 2003.Optimization of growth condition for the production of extra cellular lipase by Bacillus mycoides.Ind. J. Microbiol., 43: 67 - 69

[12] . Selva Mohan T, A Palavesam and G. Immanvel. Isolation and characterization of lipase-production Bacillus strains from oil mill waste. African journal of biotechnology 2008;2728:2735-7.

[13]. B. Vishnupriya, C. Sundaramoorthi, M. Kalaivani, K Selvam. Production of lipase from streptomycesgriseus and evaluation of Bioparameters.International journal of chemtech research 2010;1380-1383:2 